\title{
感圧塗料による燃料電池内の酸素分圧分布測定
}

\section{Measurement of oxyecoia pressure distribution in a fuel cell using pressure sensitive paint}

\author{
○ 稲垣 俊 (東北大学) 永井 大樹(東北大学) 浅井 圭介(東北大学)
}

\begin{abstract}
Suguru Inagaki, Tohoku University, 6-6-01 Aramaki Aza Aoba, Aoba-ku, Sendai, Miyagi, 980-8579 Japan Hiroki Nagai, Tohoku University, 6-6-01 Aramaki Aza Aoba, Aoba-ku, Sendai, Miyagi, 980-8579 Japan Keisuke Asai, Tohoku University, 6-6-01 Aramaki Aza Aoba, Aoba-ku, Sendai, Miyagi , 980-8579 Japan
\end{abstract}

Key Words: Pressure-sensitive paint, Fuel cell, Oxygen partial pressure distribution

\section{1. 緒論}

将来の電力需要をまかなうために, 小型で高効率なシステ ムの一つとして燃料電池(FC)が注目されている. 燃料電池と は，酸素と水素を化学的に反応させ，水を生成する過程で電 気エネルギーを得る発電装置である。この燃料電池のさらな る高効率化と寿命延長を図る上で, 電極触媒層や拡散層での 酸素分子の動的挙動および濃度分布の把握が重要な課題と なる.この要求に応える測定技術として感圧塗料(PSP)技術 が挙げられる. PSPは励起光によって色素が発した光の強度 が色素周辺の酸素濃度によって変化する現象を利用した酸 素分子センサであり, 塗料を塗布した測定対象面上の酸素分 圧分布を発光強度として 2 次元的にイメージで捉えることが 可能である ${ }^{(1)}$.

本研究では, PSP 技術を燃料電池セル内の酸素分圧分布測 定に適用し、その有用性を確認する試験を実施した。

\section{3. 実験装置}

Fig.1に計測システムの概略図を示す，可視化セパレータ 流路は上から順に流路(1)〜 (7)とし，幅・深さともに各流路 $1 \mathrm{~mm}$ ，材質はアクリルである．PSP は、スプレー塗装により 燃料電池カソード側の流路に塗布した.

光学系は, 励起光源には UV-LED を用い, 検出器にはマル チゲート CCD カメラ (分解能 $14 \mathrm{bit}$, 解像度 $1344 \times 1024$ ) 用 いた. なお検出器の前には, 励起光の反射や迷光を除去する ためバンドパスフィルタ $(\lambda=650 \pm 20 \mathrm{~nm})$ を置いた.

本実験で使用した PSP は, 色素にPtTFPP(吸収波長 $400 \mathrm{~nm}$, 励起波長 $650 \mathrm{~nm}$ ，バインダーに Polystyrene(分子量 100,000), 溶媒にトルエン, さらに撥水剤を $3 \%$ 添加したものを用いた.

\section{4. 実験結果}

Fig.2にストイキ比 $\mathrm{St}=2$, 電流密度 $0.2\left[\mathrm{~A} / \mathrm{cm}^{2}\right]$ における燃料 電池可視化セル内の流路(2), (4), (6)上の酸素分圧プロファイ ルを示す。ここで、横軸は流路の出口部を原点とした位置, 縦軸は酸素分圧 $P_{\mathrm{O} 2}[\mathrm{kPa}]$ である.この図から、全体的にガス 入口部から出口部まで流路に沿って酸素分圧が減少してい るのがわかる．ただし，流路によってその傾向は異なる．特 に流路(6)は流路に沿って酸素の消費が非常に大きいことが 分かる. 一方、流路(2)では酸素分圧分布が流路入口から出口 に沿ってフラットであり, 酸素の消費が小さい.このことは、 発電が起こらず, 流路下部に比べて流路上部では反応が起こ りにくいのではないかと考えられる。しかしながら、発電に 伴い生成した水は下方ほど溜まりやすいので、発電・流量は 均一だと仮定すれば、水滴によりガス流量が減少して、結果 的に酸素濃度が減少するといった別の解採も考えられる。

\section{5. 結論}

本研究では, PSP 技術を燃料電池セル内の酸素分圧分布測 定に適用し、その有用性を確認する試験を実施した。その結 果, 実発電実験において、燃料電池セル流路に沿った酸素分 圧分布を可視化し、ストイキ比および電流密度による違いを 明らかとすることが出来た．ただし、定量的には、局所的な 温度分布の影響のために、十分な精度では計測できなかった。 そのため, 今後定量的な測定を行うためには温度・圧力を同 時に計測できるシステムの開発が必要であると言える

\section{参考文献}

(1)T.Liu and J.sullivan,Pressure And Temperature Sensitive Paints,Springer Berlin Heideberg New York,2004

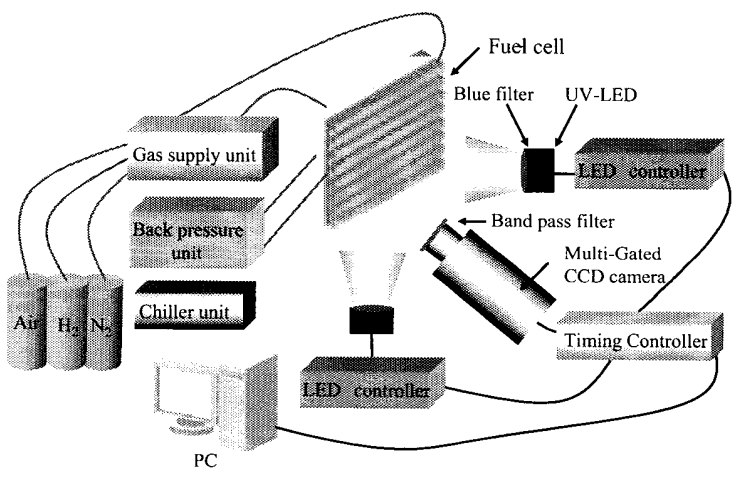

Fig.1 Schematic of measurement system

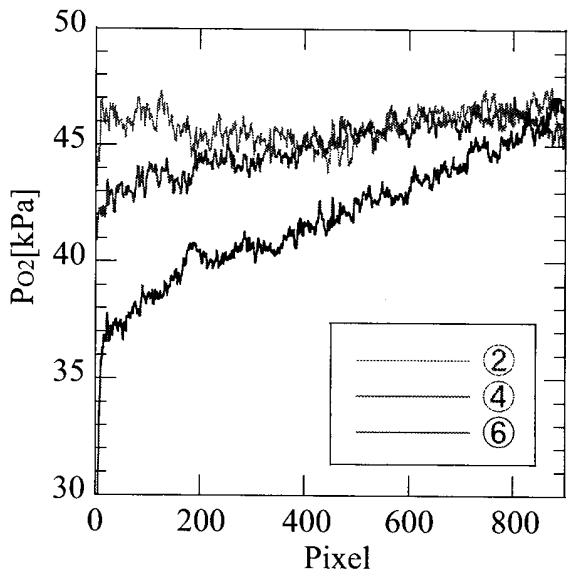

Fig.2 Oxygen partial pressure distribution along channel(2),(4),(6) 